\title{
Utilization of Chlorella sp. as biostimulant in the germination of melon seeds (Cucumis melo L.)
}

\author{
José Franciraldo de Lima \\ (Corresponding author), Center of Science and Technology, Department of Agricultural \\ Engineering, Federal University of Campina Grande, PB - Brazil \\ E-mail: josefranciraldo@gmail.com
}

\begin{abstract}
Alexandre José de Melo Queiroz
Center of Science and Technology, Department of Agricultural Engineering, Federal

University of Campina Grande, PB - Brazil

E-mail: alexandrejmq@gmail.com
\end{abstract}

\begin{abstract}
Rossana Maria Feitosa de Figueirêdo
Center of Science and Technology, Department of Agricultural Engineering, Federal University of Campina Grande, PB - Brazil

E-mail: rossanamff@gmail.com
\end{abstract}

Wagner Rodrigo de Souza

Center for Natural and Human Sciences, Federal University of ABC, SP - Brazil

E-mail: wagner.souza@ufabc.edu.br

\begin{abstract}
Hosana Maria Debonsi
Department of Biomolecular Sciences, School of Pharmaceutical Sciences of Ribeirão Preto, University of São Paulo, Ribeirão Preto, SP, Brazil. Phone: +5516 - 33154713

E-mail: hosana@fcfrp.usp.br
\end{abstract}

Vitor Francisco dos Santos

Department of Biomolecular Sciences, School of Pharmaceutical Sciences of Ribeirão Preto, University of São Paulo, Ribeirão Preto, SP, Brazil. Phone: +5516 - 33154713 
E-mail: vitor.francisco.santos@hotmail.com

\author{
Andréia Maria Nogueira Dantas \\ Center for Agrifood Sciences CCTA. Federal University of Campina Grande PB - Brazil \\ E-mail: andreia_115@hotmail.com
}

\begin{abstract}
Railene Hérica Carlos Rocha Araújo
Center for Agrifood Sciences CCTA. Federal University of Campina Grande PB - Brazil

E-mail: raileneherica.ufcg@gmail.com
\end{abstract}

Received: Apr. 2, 2020

doi:10.5296/jas.v8i2.17155
Accepted: June 4, $2020 \quad$ Published: June 8, 2020

URL: https://doi.org/10.5296/jas.v8i2.17155

\begin{abstract}
Bioactive microalgae compounds have been shown to be excellent stimulants for seed germination. This study aimed at the production of biomass of Chlorella sp. through the modulation of the culture medium and its further use as bioestimulant in melon seed germination (Cucumis melo L.). Chlorella sp. cells were grown in medium containing distinctive levels of nitrogen $(\mathrm{N})$, phosphorus $(\mathrm{P})$, potassium $(\mathrm{K})$ and carbon $(\mathrm{C})$, and analyzes of yield, hygroscopic behavior and the amino acid profile of the biomass were carried out for all treatments. In addition, mechanical hydrolysis of the biomass through high-energy wet grinding was performed, obtaining suitable particle size. After biomass characterization, an aqueous solution of the hydrolyzate was used for biostimulation of melon seeds. The different growth medium composition affected biomass yield and amino acid profile. The most significant effects for seed biostimulation were obtained during growth in medium containing intermediary or low levels of NPK and C, with germination index (GI) of 92 and $95 \%$, and germination speed index (GSI) of 8.00000 and 8,26087 seedlings.day ${ }^{-1}$, respectively. It is concluded that the modulation of the cultivation of Chlorella sp. is a viable strategy for the production of active compounds. The hydrolysates of Chlorella sp. demonstrated a biostimulant potential and can be a source of molecules for many applications in agriculture.
\end{abstract}

Keywords: microalgae, biostimulants, amino acids, Cucumis melo L

\title{
1. Introduction
}

Plant biostimulants are sets of natural molecules, which, when applied to plants or the rhizosphere in small amounts, act synergistically promoting plant growth, improving fruiting, 
nutrient absorption by the roots, increasing resistance to abiotic stresses, and do not generate waste for the environment, different from synthetic chemical stimulants (Chojnacka et al., 2014; Patrick, 2015; Ricci et al., 2019).

Algae extracts are good sources of biostimulants (Michalak et al., 2016; Michalak et al., 2017), and have received special attention due to their functional and phytochemical properties, due to the bioactive compounds in their composition, including high levels of proteins, peptides, essential amino acids and plant hormones (cytokinins, auxins, gibberellins, abscisic acid and ethylene) (Khan et al., 2009; Stirk et al., 2013; Stirk et al., 2013). Some microalgae species such as Scenedesmus obliquo, Chlorella sp. and Spirulina platensis, have been presented as a good source of raw material for the production of plant biotimulants, and these have been used in all stages of agricultural production, including as seed treatment, as leaf sprays during growth and in harvested products (Guedes et al., 2018; Dias et al., 2019). The action of the mode / mechanisms of "biostimulants" is equally diverse and may include activation of nitrogen metabolism or release of phosphorus in soils, general stimulation of soil microbial activity or stimulation of plant root growth (Yakhin et al., 2017).

Chlorella sp. is a green microalga that inhabits salt and sweet waters, belonging to the Chlorophyceae class, and its biomass is mostly made up of $60 \%$ proteins, with lower concentrations of fats, fibers, carbohydrates, vitamins (folic acid lutein, B vitamins, E vitamins and beta carotene) and minerals (iron, calcium, potassium, zinc, manganese, selenium, magnesium). Approximately 2000 tons of biomass / year of this species are produced in over 70 countries (Zielinski et al., 2020) and the biomass of Chlorella sp. have in their composition an elementary amount of potentially active substances, capable of exerting biological effect in many plant species, as they contain some amino acids such as tryptophan and arginine, which improve the growth and yield of cultivated crops, and are metabolic precursors of the main phytohormones in plants (Colla et al., 2014; Colla et al., 2016; Colla and Rouphael, 2015; Rouphael and Colla, 2018). It is known that adequate concentrations of these amino acids promote stimulation of hormonal synthesis in plant pathways (Stirk et al., 2013).

The commercial preservation of microalgae is made possible by drying to moisture levels that prevent chemical, biochemical, and microbiological deterioration. After drying, the material remains stable if it does not adsorb water in the form of vapor present in the surrounding environment. Algae biomass is composed by numerous constituents that can influence its hygroscopicity, defined by the behavior of moisture adsorption isotherms. One of the main applications of equations describing isotherms refers to the energy of water bonds and their adsorption on the surface of materials. It is also necessary to consider the characteristics of the molecular monolayer of water, which are directly linked to the chemical reactions that occur in the deterioration of biological materials due to solid matrix response areas (Sanchez et al., 2008; Konig-Péter et al., 2015). Studies to predict the behavior of isotherms through model adjustments have sought to define the behavior of many materials of biological origin, which helps to explain the characteristics of each material and its reactivity over time (Rezaei et al., 2011; Jelínek et al., 2015). Most of these models are empirical, and due to the characteristics of each material, it is more difficult to find generalist models that can be used 


\section{Macrothink}

in all matrices (Park et al., 2014). The biomass of Chlorella sp. is composed of a multivariate class of compounds whose nature determines their hygroscopic behavior, providing information for the proper conservation of the constituents of interest (Cui et al., 2018).

Here, we aimed to modulate the cultivation of the microalgae Chlorella sp. in different concentrations of nutrients. In addition, it was evaluated the hygroscopic behavior of the biomass, using isotherms of water adsorption at $25^{\circ} \mathrm{C}$. The analysis of amino acid profile produced during cultivation, the mechanical hydrolysis of the biomass and its granulometry were also performed. Subsequently, the hydrolyzed biomass was used as a potential biostimulant for seed germination of melon (Cucumis melo L.).

\section{Material and Methods}

A flowchart of the stages of the cultivation and processing of microalgae Chlorella sp. and the stages of the analysis of biostimulation of seed germination is shown in Figure 1.

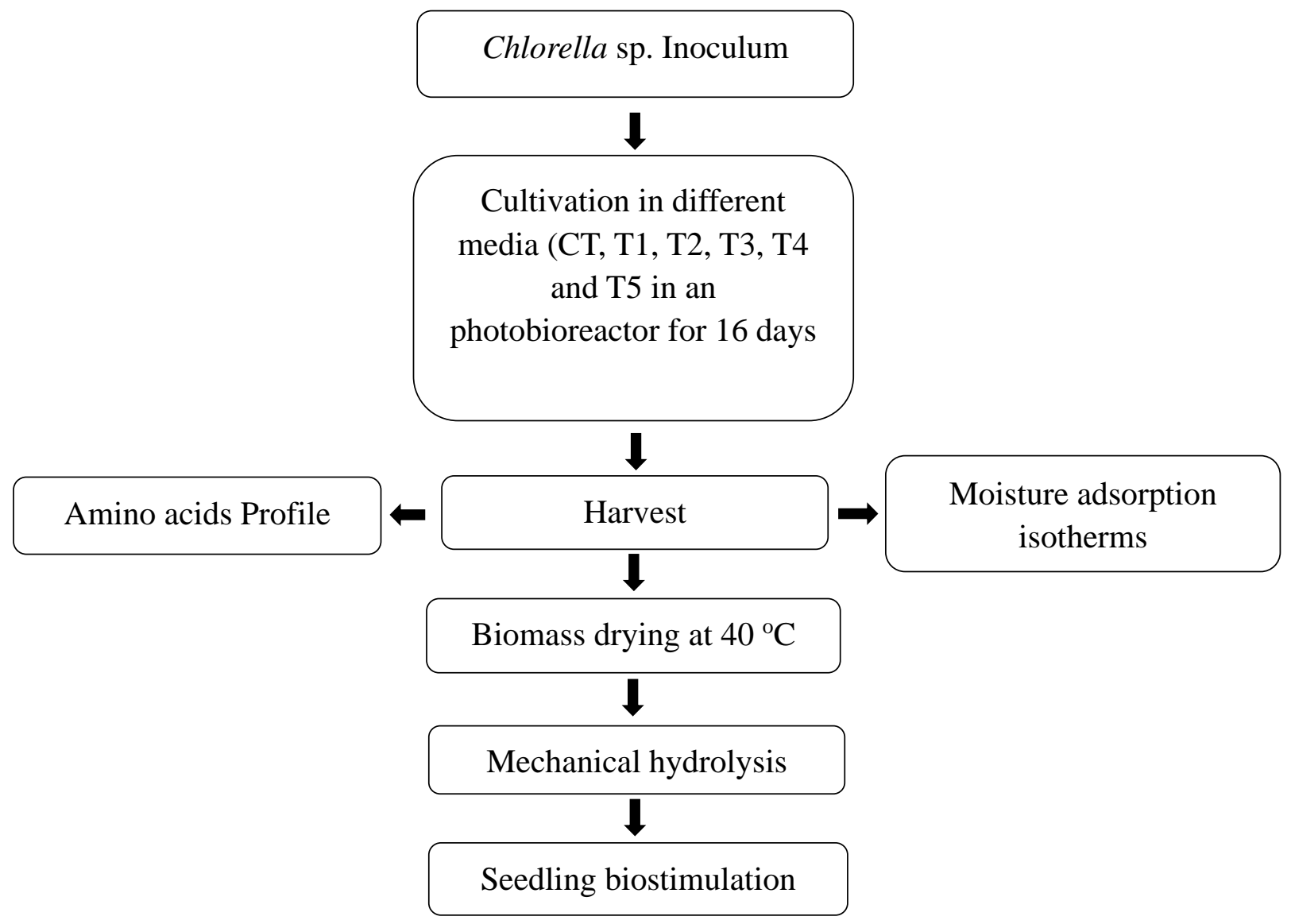

Figure 1. Flowchart of the cultivation and processing steps of the microalgae Chlorella sp

\subsection{Microalgae Cultivation}

The microalgae (Chlorella sp.) used in this work were grown in open photobioreactors, "raceway model", exposed to sunlight, with a volume of $10 \mathrm{~m}^{3}$, with agitation performed with an axial aerator (Aeromack, CRE-01) with continuous flow of $1.4 \mathrm{~m}^{3} / \mathrm{min}$, pressure of 1,200 mca, power of $0.5 \mathrm{HP}$. The culture medium was prepared according to (Watanabe, 1960; 
Becker, 1994; Morais, 2007; Baumgartner, et al., 2013), called "Medium for Chlorella ellipsoidea", composed by $\mathrm{KNO}_{3}$ nitrate potassium $1.25 \mathrm{~g} / \mathrm{L}, \mathrm{KH}_{2} \mathrm{PO}_{4}$ monopotassium phosphate $1.25 \mathrm{~g} / \mathrm{L}, \mathrm{MgSO}_{4} .7 \mathrm{H}_{2} \mathrm{O}, \mathrm{FeSO}_{4}$ iron sulphate heptahydrate $0.02 \mathrm{~g} / \mathrm{L}, \mathrm{A}_{5}$ (micronutrients $1 \mathrm{~mL} / \mathrm{L}$ solution composed of $\mathrm{H}_{3} \mathrm{BO}_{3}$ boric acid $2.90 \mathrm{~g} / \mathrm{L}, \mathrm{MnCl}_{2} .4 \mathrm{H}_{2} \mathrm{O}$ manganese chloride tetrahydrate $1.81 \mathrm{~g} / \mathrm{L}, \mathrm{ZnCl}_{2}$ zinc chloride $0.11 \mathrm{~g} / \mathrm{L}, \mathrm{CuSO}_{4} .5 \mathrm{H}_{2} \mathrm{O}$ copper sulfate pentahydrate $0.08 \mathrm{~g} / \mathrm{L}, 3\left(\mathrm{NH}_{4}\right)_{2} \mathrm{O} .7 \mathrm{MoO}_{3} .4 \mathrm{H}_{2} \mathrm{O}$, ammonium selenate tetrahydrate $0.018 \mathrm{~g} / \mathrm{L}$, with changes in nutrient concentrations, corresponding to treatments with CT (control without changes in nutrient concentrations), T1, T2, T3, T4 and T5 as described in (Table 1).

Table 1. Concentration of chemical constituents for culture modulation Chlorella sp. for the different treatments

\begin{tabular}{ccccc}
\hline Treatments & $\mathrm{KNO}_{3}(\mathrm{~g} / \mathrm{L})$ & $\mathrm{KH}_{2} \mathrm{PO}_{4}(\mathrm{~g} / \mathrm{L})$ & $\begin{array}{c}\mathrm{FeSO}_{4} 7 \mathrm{H} 2 \mathrm{O} \\
(\mathrm{mg} / \mathrm{L})\end{array}$ & $\mathrm{NaHCO}_{3}(\%)$ \\
$\mathrm{CT}$ & 1.250 & 1.250 & 10.00 & 0.04 \\
$\mathrm{~T} 1$ & 0.625 & 0.625 & 5.00 & 0.04 \\
$\mathrm{~T} 2$ & 0.313 & 0.313 & 2.50 & 0.06 \\
$\mathrm{~T} 3$ & 0.157 & 0.157 & 1.25 & 0.08 \\
$\mathrm{~T} 4$ & 0.157 & 0.157 & 1.25 & 0.10 \\
$\mathrm{~T} 5$ & 0.157 & 0.157 & 1.25 & 0.12 \\
\hline
\end{tabular}

Figure 1 shows the flowchart of the steps from cultivation to microalgae processing after 16 days of cultivation. Microalgae harvesting from different treatments was performed by flocculation with aluminum sulfate $\left(\mathrm{Al}_{2}\left(\mathrm{SO}_{4}\right) \mathrm{H}_{2} \mathrm{O}\right)$ with a concentration of $0.5 \mathrm{~g} / \mathrm{L}$ for 30 minutes (Lira, 2011), followed by decantation. The decanted biomass of Chlorella sp. was placed on a 325 mesh nylon filter for 3 hours and then dried in a forced air circulation oven at $40{ }^{\circ} \mathrm{C}$ and $2 \mathrm{~m} / \mathrm{s}$ air velocity. After, the biomass was distributed in trays on slides with thicknesses of $0.3 \mathrm{~cm}$ and $0.5 \mathrm{~cm}$ in width and constant weight. After drying, the biomass was removed from the trays and ground in a hammer mill with a rotation speed of $8000 \mathrm{rpm}$ and $0.5 \mathrm{~mm}$ sieve, obtaining the biomass powder from different treatments.

\subsection{Moisture Adsorption Isotherms}

The evaluation of the moisture adsorption isotherms at $25{ }^{\circ} \mathrm{C}$ of Chlorella $\mathrm{sp}$. The different treatments were determined in triplicate using the static-indirect method (Crapiste \& Rotstein, 1982). Water activity readings were taken using a Decal Devices Aqualab model 3TE hygrometer and the equilibrium moisture content determined at $105 \mathrm{oC}$ until constant weight. The GAB (Equation 1), Oswin (Equation 2) and Peleg (Equation 3) mathematical models 


\section{Il Macrothink}

were adjusted to the moisture adsorption isotherms by nonlinear regression by the Quasi-Newton estimation method, using the Statistica software.

$$
X_{e}=\frac{X_{m} C K a_{w}}{\left(1-\mathrm{Ka}_{w}\right)\left(1-\mathrm{Ka}_{w}+\mathrm{CKa}_{\mathrm{w}}\right)}
$$

On what:

$\mathrm{X}_{\mathrm{e}}$ - equilibrium moisture content;

aw - water activity;

$\mathrm{X}_{\mathrm{m}}$ - moisture in the molecular monolayer;

$\mathrm{C}$ e $\mathrm{K}$ - parameters that depend on the temperature of the nature of the product.

$$
X_{e}=a\left(\frac{a_{w}}{\left(1-a_{w}\right)}\right)^{b}
$$

On what:

$\mathrm{X}_{\mathrm{e}}$ - equilibrium moisture content

$\mathrm{a}_{\mathrm{w}}$ - water activity

$\mathrm{a}$ e $\mathrm{b}$ - model tuning parameters

$$
\mathrm{X}_{\mathrm{e}}=\mathrm{K}_{1} \mathrm{a}_{\mathrm{w}}^{\mathrm{n}_{1}}+\mathrm{K}_{2} \mathrm{a}_{\mathrm{w}}^{\mathrm{n}_{2}}
$$

On what:

$\mathrm{Xe}$ - equilibrium moisture content

$\mathrm{K}_{1}$ e $\mathrm{K}_{2}$ - constants of the equation

$\mathrm{a}_{\mathrm{w}}$ - water activity

$\mathrm{n}_{1}$ e $\mathrm{n}_{2}$ - constants of the equation

The criteria used to determine the best fit of the models to the isotherms were the coefficient of determination $\left(\mathrm{R}^{2}\right)$ and the mean percentage deviation $(\mathrm{P})$, calculated according to Equation 4.

$$
\mathrm{P}=\frac{100}{n} \cdot \sum_{i=1}^{n} \frac{\left|\left(\mathrm{X}_{\exp }-\mathrm{X}_{\text {teor }}\right)\right|}{\mathrm{X}_{\exp }}
$$

on what:

$$
\mathrm{P} \text { - mean percentage deviation (\%); }
$$


$\mathrm{X}_{\text {exp- }}$ experimentally obtained values;

$\mathrm{X}_{\text {teor }}$ - values predicted by the model;

$\mathrm{n}$ - number of experimental data

\subsection{Amino Acid Profile Analysis}

The determination of the amino acid profile in Chlorella sp. grown in different treatments was performed by the derivatization method using phenylisothiocyanate (PITC), after acid hydrolysis. A mixture of various amino acids was obtained, which were further subjected to analysis by high performance liquid chromatography (HPLC).

The proteins contained in the biomass powders were hydrolyzed at $110{ }^{\circ} \mathrm{C}$ with $6 \mathrm{~N}$ hydrochloric acid for 24 hours. PITC-reacted amino acids released in acid hydrolysis (Hagen et al., 1989) were separated by reverse phase HPLC using LUNA C18 column $(100 \AA, 5 \mu \mathrm{m}$ 250 x $4.6 \mathrm{~mm}$; code 00G-4252-EQ), and quantified by UV detector at $254 \mathrm{~nm}$.

Quantification was performed by multilevel internal calibration using $\alpha$-aminobutyric acid (AAAB) as the internal standard (White et al., 1986). For the calculation of the content of each amino acid the molecular weight value of each amino acid was taken in condensed form, ie the full molecular weight of the amino acid, decreased by 18 a.m. (mass of a molecule of water) so as to consider the amino acid as being in its protein form. Tryptophan values were determined by spectrophotometry in alkaline medium.

The sample was subjected to enzymatic hydrolysis with pronase at $40{ }^{\circ} \mathrm{C}$ for $24 \mathrm{~h}$, then subjected to colorimetric reaction with $p$-dimethylene benzaldehyde (DAB) and read at 590 $\mathrm{nm}$ spectrophotometer (Spies, 1967). Tryptophan concentration was calculated by comparison with the standard curve.

\subsection{Mechanical Hydrolysis and Analysis (SEM)}

To perform mechanical hydrolysis, $50 \mathrm{~g}$ of the biomass of each treatment was weighed in triplicate, and introduced in stainless steel milling stations, with a capacity of $400 \mathrm{~mL}$, containing $20 \mathrm{~mL}$ of distilled water and 10 stainless steel balls of $10 \mathrm{~mm}$ in diameter. After, the biomass was processed in 0.4 L NOAH NQM planetary ball mill (China) with speed of $400 \mathrm{rpm}$, grinding times 5, 10, 15 and $20 \mathrm{~min}$, based on Bello and co-workers (2015), with modifications. At the end of each grinding, the material was collected and dried under vacuum, and analyzed by scanning electron microscopy (SEM). For (SEM) analyses, the samples were fixed in a sample holder with the aid of carbon tape, and metallized with a conductive film, formed by a gold / palladium alloy and later analyzed in a scanning electron microscope (Shimadzu, SSX- 550), operating $15 \mathrm{KV}$, with an image increase of x2000. To determine the particle size ranges, the software Image-Pro Plus 7.0 (Media Cybernetics) was used.

\subsection{Seed Germination}

The seed germination was carried out with four replications of 50 yellow melon seeds, for each treatment, conducted in a greenhouse, at the Center for Science and Agri-Food 
Technology - CCTA, Federal University of Campina Grande - UFCG, Campus Pombal, PB, at the geographical coordinates $6^{\circ} 48^{\prime} 16^{\prime \prime}$ south latitude and 37\%49'15" longitude west, and altitude of $175 \mathrm{~m}$. The climate of this region, according to Köppen, is of the Aw type, called semi-arid, hot and dry, with summer rains, with temperatures above $25^{\circ} \mathrm{C}$ and rainfall of 650 $\mathrm{mm}$ year irregularly distributed (Melo et al. 2008).

The substrate used for seed germination was Chromic Luvisol, autoclaved at $120^{\circ} \mathrm{C}$ for 4 hours. Then, the substrate was arranged in 6 polystyrene trays of 200 cells, filling all cells in each tray evenly. For biostimulation of melon seeds. 6 aqueous solutions were prepared containing hydrolyzate from Chlorella sp. CT, T1, T2, T3, T4 and T5 treatments, with a final concentration of $1.5 \mathrm{mg} / \mathrm{mL}$. Each solution was transferred to a $500 \mathrm{~mL}$ Erlenmeyer, and incubated at $70^{\circ} \mathrm{C}$ for 15 minutes, with magnetic stirring at $300 \mathrm{rpm}$, in a magnetic heating shaker, based on (Navarro-Lopéz et al., 2020). Then, $10 \mathrm{~g}$ of yellow melon seeds were introduced for each of the six prepared solutions and left to rest for 6 hours before sowing. The sowing was performed in polystyrene trays of 200 cells, using seeds that were biostimulated, by sowing a seed in each cell of the tray. The irrigations throughout the experiment were carried out twice a day, at 9 am and at $4 \mathrm{pm}$.

The evaluation of seedling emergence was determined by reduced counts of seedlings emerging until stabilization, which occurred up to 10 days after sowing, considering that they emerged as seedlings with exposed cotyledons. To determine the emergency speed index (IVE), use an equation proposed by Maguire, (1962): IVE = E1 / N1 + E2 / N2 + .. + En / Nn; where: E1, E2, En = number of normal seedlings observed in the first, second and last count; $\mathrm{N} 1, \mathrm{~N} 2, \mathrm{Nn}=$ number of sowing days in the first, second and last count. After stabilization, an emergency percentage was determined using the formula: $\% \mathrm{E}=\mathrm{N} / \mathrm{A}$, where $\mathrm{N}=$ number of seeds emerged; $\mathrm{A}=$ total number of seeds sown. Average germination time calculated according to the formula proposed by Labouriau (1983), with results expressed in days.

At 25 days after sowing, plants were harvested, washed to remove the substrate adhered to them and taken to the laboratory, where the following variables were considered: number of leaves (NL), length of the aerial parts, (LAP), length of the root (LR), diameter of the capsule measured with the aid of a caliper, fresh mass of the aerial part (FMAP), fresh root mass (FRM) dry mass of the aerial part (DMAP), dry mass of the root (DMR). To determine the dry mass, the plant material was placed in an oven with forced air circulation, at $95^{\circ} \mathrm{C}$, until constant mass was obtained. An analysis of variance was used to verify the effect of bioestimulation, followed by the Tukey test with 5\% probability, using the SISVAR computer program (Ferreira, 2011).

\section{Results and Discussion}

\subsection{Microalgae Cultivation}

Table 2 presents the average values of the data referring to dry weight of Chlorella $\mathrm{sp}$. biomass in the CT, T1, T2, T3, T4 and T5 treatments. The most expressive results were obtained when the microalgae was grown in the control treatment, where the biomass reached $4.85 \mathrm{~g} / \mathrm{L}$ of dry biomass on the $10^{\text {th }}$ day, followed by $\mathrm{T} 1$ treatment, which yielded $4.75 \mathrm{~g} / \mathrm{L}$ of 
dry biomass on the $10^{\text {th }}$ day. Cell growth in treatment $\mathrm{T} 2$ did not show significant difference between days 10, 12, 14 and 16, with average values of 3.63, 3.79, 3.57 and $3.58 \mathrm{~g} / \mathrm{L}$ of dry biomass, respectively; in treatment $\mathrm{T} 3$ the best growth was achieved on the $12^{\text {th }}$ day of cultivation with $2.63 \mathrm{~g} / \mathrm{L}$ of dry biomass. Moreover, treatment T4 had the greatest growth on the $16^{\text {th }}$ day with $2.86 \mathrm{~g} / \mathrm{L}$ of dry biomass, and the T5 treatment showed the highest growth in the $14^{\text {th }}$ with $1.77 \mathrm{~g} / \mathrm{L}$ of dry biomass, but there were no significant differences between the averages at the times $10,12,14$ and 16 days indicating that, statistically, the $10^{\text {th }}$ day can be considered as the maximum growth.

Although each element in the medium has its relative importance for algae nutrition, there is no exact number of essential chemical elements, as certain elements are essential for certain species and are not essential for others (Baumgatner et al., 2013). Among the elements contained in the formulation of the culture medium, nitrogen $(\mathrm{N})$ is considered to be the most important because it is the constituent element of many compounds of the primary metabolism, its abundance in the culture medium can favor the synthesis of proteins and chlorophyll and its deficiency tends to reduce cell growth rates (Lourenço, 2006; Bertoldi, 2008). Moreover, the deprivation of nitrogen, phosphorus and potassium might induce the cells to a growth route with priority in the intracellular reserve stock, to support the scarcity of these nutrients, showing that an adjustment in the ideal amount of NPK can result in the production of biomass in greater volume, along with other products of interest, such as carbohydrates and lipids (Martin et al., 2014).

Table 2. Average values of dry weight of Chlorella sp. (g/ L) during the cultivation in different treatments

\begin{tabular}{ccccccc}
\hline \multirow{2}{*}{$\begin{array}{c}\text { Time } \\
\text { (day) }\end{array}$} & \multicolumn{7}{c}{ Dry weight $(\mathrm{g} / \mathrm{L})$} \\
\cline { 2 - 7 } & $\mathrm{CT}$ & $\mathrm{T} 1$ & $\mathrm{~T} 2$ & $\mathrm{~T} 3$ & $\mathrm{~T} 4$ & $\mathrm{~T} 5$ \\
\hline 1 & $0.34 \mathrm{gA}$ & $0.34 \mathrm{fA}$ & $0.33 \mathrm{fA}$ & $0.38 \mathrm{fA}$ & $0.36 \mathrm{gA}$ & $0.39 \mathrm{eA}$ \\
2 & $1.03 \mathrm{fA}$ & $1.06 \mathrm{eA}$ & $0.90 \mathrm{eAB}$ & $0.63 \mathrm{eC}$ & $0.60 \mathrm{gC}$ & $0.77 \mathrm{dBC}$ \\
4 & $2.80 \mathrm{eA}$ & $2.61 \mathrm{dA}$ & $2.00 \mathrm{~dB}$ & $1.34 \mathrm{dC}$ & $0.97 \mathrm{fD}$ & $1.08 \mathrm{cD}$ \\
6 & $3.67 \mathrm{dA}$ & $3.73 \mathrm{cA}$ & $2.91 \mathrm{cB}$ & $1.82 \mathrm{cC}$ & $1.30 \mathrm{eD}$ & $1.13 \mathrm{cD}$ \\
8 & $4.33 \mathrm{cA}$ & $4.05 \mathrm{bB}$ & $3.22 \mathrm{bC}$ & $2.00 \mathrm{cD}$ & $1.82 \mathrm{dD}$ & $1.42 \mathrm{bE}$ \\
10 & $4.85 \mathrm{aA}$ & $4.75 \mathrm{aA}$ & $3.63 \mathrm{aB}$ & $2.33 \mathrm{bC}$ & $2.00 \mathrm{cdD}$ & $1.64 \mathrm{abE}$ \\
12 & $4.69 \mathrm{abA}$ & $4.21 \mathrm{bB}$ & $3.79 \mathrm{aC}$ & $2.63 \mathrm{aD}$ & $2.18 \mathrm{cE}$ & $1.77 \mathrm{aF}$ \\
14 & $4.61 \mathrm{abA}$ & $4.09 \mathrm{bB}$ & $3.57 \mathrm{aC}$ & $2.50 \mathrm{abD}$ & $2.53 \mathrm{bD}$ & $1.75 \mathrm{aE}$ \\
16 & $4.54 \mathrm{bcA}$ & $4.01 \mathrm{bB}$ & $3.58 \mathrm{aC}$ & $2.43 \mathrm{abE}$ & $2.86 \mathrm{aD}$ & $1.66 \mathrm{abF}$ \\
\hline
\end{tabular}

$\mathrm{GM}=2.34 ; \mathrm{CV}=4.04 \% ; \mathrm{SMD}$ for columns $=0.24 ; \mathrm{SMD}$ for lines $=0.22 ; \mathrm{GM}-$ General average; CV - Coefficient of variation; SMD - Significant minimum deviation note: Averages followed by the same lowercase letter in the columns and uppercase in the lines do not differ statistically by the Tukey test, at $5 \%$ probability.

As observed, the increase of the carbon source in treatments T3, T4 and T5, did not favor the increase of the cellular concentration (Tables 1 and 2), suggesting that nitrogen was not the limiting factor for the reduction of cell growth, but the element phosphorus $(\mathrm{P})$, as this element is necessary for the normal growth of algae. Potassium is the element of greatest 
abundance in the culture medium; however, it was also not the limiting factor for cell growth in this study

The biomass production was, in all treatments, satisfactory, when compared with the production reported by Matos (2012), working with Chlorella vulgaris grown in BBM (Bold Basal Medium), producing $0.590 \mathrm{~g} / \mathrm{L}$ of dry biomass; by Li et al. (2011) producing $2.83 \mathrm{~g} /$ L of dry biomass of Chlorella vulgaris using the SRH (hydroponic residual solution) and glucose as a carbon source; by Putri et al. (2011) with a production of Chlorella vulgaris of $0.118 \mathrm{~g} / \mathrm{L}$, Chlorella pyrenoidosa of $0.058 \mathrm{~g} / \mathrm{L}$ and Chlorella sorokiana of $0.160 \mathrm{~g} / \mathrm{L}$ by Niels et al. (2012) with a production of Chlorella sp. $0.410 \mathrm{~g} / \mathrm{L}$ and very short $0.490 \mathrm{~g} / \mathrm{L}$ Chlorella using the modified BG11 (blue green medium) culture medium and by Mokashi et al. (2016) with productivity of $0.160 \mathrm{~g} / \mathrm{L}$ of dry biomass in the cultivation of Chlorella vulgaris with BG11 culture medium (blue green medium). It is concluded that the cell growth obtained in this work is in accordance with the literature.

\subsection{Moisture Adsorption Isotherms}

We analyzed moisture adsorption isotherms at $25^{\circ} \mathrm{C}$ of Chlorella sp. submitted to different treatments. Table 3 shows the parameter values of the Oswin, GAB and Peleg models adjusted to the $25{ }^{\circ} \mathrm{C}$ moisture adsorption isotherms of Chlorella sp. for CT, T1, T2, T3, T4 and T5 treatments, in addition to the determination coefficients $\left(\mathrm{R}^{2}\right)$ and the mean percentage deviations $(\mathrm{P})$.

All determination coefficients $\left(\mathrm{R}^{2}\right)$ showed values above 0.97 and mean percentage deviations (P) below 10\%, indicating that all models tested (GAB, Peleg and Oswin) for the prediction of moisture adsorption isotherms of biomass can be used accurately. Several researchers have found good estimates of isotherms with these models (Alexandre et al., 2007; Lima et al., 2008; Silva et al., 2015; Ribeiro et al., 2016; Trevisan, et al., 2019). The model that best fit the experimental isotherm data for the CT, T1, T2 and T4 treatments was Peleg, and for the T3 and T5 treatments, GAB. This behavior was expected due to the larger number of parameters of these models.

It is verified for Oswin's model that the constant 'a' had values ranging from 4.9262 (T4) to 6.1936 (T2) and for the 'b' constant from 0.5134 (T3) to 0.6295 (T4), being in agreement with Alexandre et al. (2007), which mentioned that for this model the values for the constant 'a' must be greater than zero and for the constant ' $b$ ' must be between zero and 1.0. Close values were found for the water adsorption isotherm at $20{ }^{\circ} \mathrm{C}$ of dried mango residual fiber flour, with 'a' equal to 7.79 and 'b' equal to 0.88 (Silva et al., 2015).

The GAB model presented moisture values in the molecular monolayer $(\mathrm{Xm})$ ranging from 2.8427 (CT) to $9.4789 \%$ (T4). The value of Xm indicates the amount of water that is strongly adsorbed to the active sites on the surface of the products and is also related to the stability of the product, being considered as the best value to guarantee stability (Gabas et al., 2009; Fabra et al., 2011). Moisture levels in the molecular monolayer (Xm) within this range were found for dried spirulina, with values of 6.9, 7.3 and 8.2\%, at temperatures of 10, 20 and 30 ${ }^{\circ} \mathrm{C}$, respectively (Oliveira et al., 2009a). 


\section{Macrothink}

The constant $\mathrm{C}$ determines the binding force of water molecules to the primary sites on the product surface (Bhusari et al., 2016), and ranged from 0.3951 (T4) to 117.1637 (CT). Oliveira et al. (2009b) found for Spirulina platensis C values ranging from 36.14 to 37.41.

The constant $\mathrm{K}$ of the GAB model ranged from 0.8278 to 0.9499 , with values close to that determined by Oliveira et al. (2009a) for the adsorption isotherms of dried spirulina, which ranged from 0.92 to 0.97 . The $\mathrm{K}$ value provides a measure of the interactions between molecules in the multilayer and the adsorbent and tends to lie between the energy value of the molecules in the monolayer and liquid water (Cano-Higuita et al., 2015).

Analyzing the values of the parameters $\mathrm{K}$ and $\mathrm{C}$ of the GAB model and according to the Blahovec (2004) classification, the moisture adsorption isotherms of the powder biomass for the treatments CT, T1 and T5 were classified as type II $(0<\mathrm{K} \leq 1, \mathrm{C}>2)$ and for T2, T3 and T4 as type III $(0<\mathrm{K} \leq 1,0 \leq \mathrm{C} \leq 2)$.

Table 3. Parameters, coefficients of determination $\left(\mathrm{R}^{2}\right)$ and mean percentage deviations $(\mathrm{P})$ of the Oswin, GAB and Peleg models adjusted to the moisture adsorption isotherms at $25{ }^{\circ} \mathrm{C}$ of Chlorella sp. for TC, T1, T2, T3, T4 and T5 treatments

\begin{tabular}{|c|c|c|c|c|c|c|c|}
\hline \multirow{2}{*}{$\begin{array}{c}\text { Treatment } \\
\text { Model }\end{array}$} & & \multicolumn{4}{|c|}{ Parameter } & \multirow{2}{*}{$\mathrm{R}^{2}$} & \multirow{2}{*}{$\begin{array}{c}\mathrm{P} \\
(\%)\end{array}$} \\
\hline & & \multicolumn{2}{|r|}{$\mathrm{a}$} & \multicolumn{2}{|r|}{$\mathrm{b}$} & & \\
\hline \multirow{6}{*}{ Oswin } & $\mathrm{CT}$ & \multicolumn{2}{|c|}{5.3563} & \multicolumn{2}{|c|}{0.5237} & 0.9974 & 2.04 \\
\hline & $\mathrm{T} 1$ & \multicolumn{2}{|c|}{5.7243} & \multicolumn{2}{|c|}{0.5278} & 0.9868 & 5.56 \\
\hline & $\mathrm{T} 2$ & \multicolumn{2}{|c|}{6.1936} & \multicolumn{2}{|c|}{0.5313} & 0.9834 & 5.02 \\
\hline & $\mathrm{T} 3$ & \multicolumn{2}{|c|}{5.1677} & \multicolumn{2}{|c|}{0.5134} & 0.9842 & 7.42 \\
\hline & $\mathrm{T} 4$ & \multicolumn{2}{|c|}{4.9262} & \multicolumn{2}{|c|}{0.6295} & 0.9860 & 7.42 \\
\hline & $\mathrm{T} 5$ & \multicolumn{2}{|c|}{5.9119} & \multicolumn{2}{|c|}{0.6019} & 0.9980 & 1.36 \\
\hline \multirow{7}{*}{ GAB } & Parameter & \multicolumn{2}{|c|}{$X_{m}$} & $\mathrm{C}$ & K & $\mathrm{R}^{2}$ & $\begin{array}{c}\mathrm{P} \\
(\%)\end{array}$ \\
\hline & $\mathrm{CT}$ & \multicolumn{2}{|c|}{2.8427} & 117.1637 & 0.9267 & 0.9941 & 2.86 \\
\hline & $\mathrm{T} 1$ & \multicolumn{2}{|c|}{3.1491} & 33.1764 & 0.9220 & 0.9909 & 4.69 \\
\hline & $\mathrm{T} 2$ & \multicolumn{2}{|c|}{4.4858} & 2.5589 & 0.8853 & 0.9918 & 4.84 \\
\hline & $\mathrm{T} 3$ & \multicolumn{2}{|c|}{4.4257} & 2.0589 & 0.9064 & 0.9933 & 5.20 \\
\hline & $\mathrm{T} 4$ & \multicolumn{2}{|c|}{9.4789} & 0.3951 & 0.8278 & 0.9960 & 3.81 \\
\hline & T5 & \multicolumn{2}{|c|}{3.2570} & 68.7968 & 0.9499 & 0.9987 & 2.33 \\
\hline \multirow{7}{*}{ Peleg } & Parameter & $\mathrm{K}_{1}$ & $\mathrm{n}_{1}$ & $\mathrm{~K}_{2}$ & $\mathrm{n}_{2}$ & $\mathrm{R}^{2}$ & $\begin{array}{c}\mathrm{P} \\
(\%)\end{array}$ \\
\hline & $\mathrm{CT}$ & 30.8481 & 17.749 & 13.7767 & 1.2627 & 0.9989 & 1.36 \\
\hline & $\mathrm{T} 1$ & 25.3102 & 6.7153 & 6.1091 & 0.0252 & 0.9958 & 2.52 \\
\hline & $\mathrm{T} 2$ & 6.0412 & 0.2670 & 25.5107 & 5.4444 & 0.9960 & 2.61 \\
\hline & $\mathrm{T} 3$ & 24.2719 & 4.1146 & 1.7216 & -1.036 & 0.9871 & 6.49 \\
\hline & $\mathrm{T} 4$ & 29.5145 & 5.4416 & 3.4002 & -0.054 & 0.9977 & 1.69 \\
\hline & $\mathrm{T} 5$ & 34.7553 & 10.0032 & 11.4451 & 0.79226 & 0.9979 & 2.66 \\
\hline
\end{tabular}



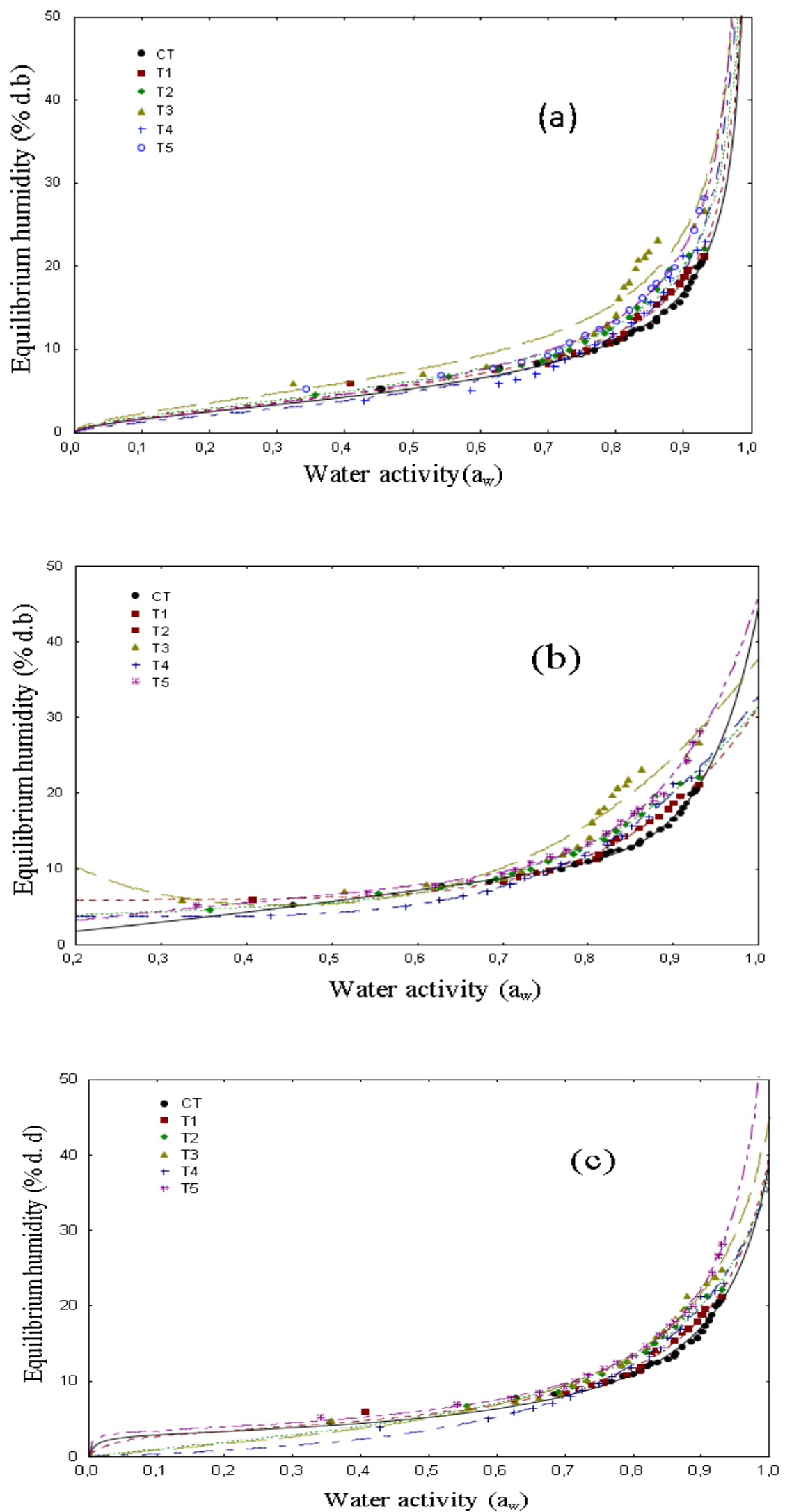

Figure 2. Moisture adsorption isotherms at $25^{\circ} \mathrm{C}$ of Chlorella sp. for the different treatments with adjustments of Oswin (a), GAB (b) and Peleg (c) 
Figure 2 shows the moisture adsorption isotherms at $25^{\circ} \mathrm{C}$ of Chlorella sp. for CT, T1, T2, T3, T4 and T5 treatments adjusted by Oswin, GAB and Peleg models. Type III water adsorption isotherms are J-shaped and, according to the classification by Brunauer et al. (1940) are generally typical of foods rich in soluble compounds, such as foods high in sugars or salts; and Type II are S-shaped sigmoidal, typical of soluble products, with asymptotic tendency. Potato starch, amylopectin and amylose powder isotherms have also been classified as Type II (Al-Muhtaseb et al., 2004).

The equilibrium moisture content (Xeq) of the samples increased with increasing water activity (aw) and ranged from 3.84 to $28.30 \%$ b.s. All treatments had very similar equilibrium humidity, with few variations, justified by the small differences in the composition of the samples. Alcântara et al. (2009) also verified for the moisture adsorption isotherm at $25{ }^{\circ} \mathrm{C}$ of the cashew dry peduncle that with the increase of aw there was an increase of Xeq and that in the aw of 0.86 to Xeq was $29.42 \%$ bs, results similar to that of Chlorella sp., which in $\mathrm{a}_{\mathrm{w}}$ of 0.93 presented Xeq of $28.30 \%$ b.s., even having very different chemical compositions. The same trend was found for the Peleg model by several researchers (McMinn \& Magee, 2003; Aguirre-Cruz et al., 2010; Claudera-Oliveira et al., 2011; Chisté et al., 2012; Spada et al., 2013). According to Goula et al. (2008), water adsorption in food is a complex phenomenon and the main constituents of food water adsorption are polymers such as proteins, starch, cellulose and hemicellulose.

\subsection{Amino Acid Profile}

Table 4 shows the results of the amino acid profile of Chlorella sp. submitted to different treatments. The total amino acid content ranged from 17.79 to $36.56 \mathrm{~g} / 100 \mathrm{~g}$, with the lowest concentration for the T5 treatment and the highest concentration for CT, respectively. Higher amino acid values were quantified in the Chlorella vulgaris biomass grown in triple fertilizer 15 medium (Nutrimon 15-15-15®) yielding a total of $41.41 \mathrm{~g} / 100 \mathrm{~g}$ amino acids (Anastasakis \& Ross, 2011) and in Chlorella biomass grown in BBM (Bold Basal Medium) medium which obtained $39.9 \mathrm{~g} / 100 \mathrm{~g}$. Similar results of amino acid levels obtained from treatments T2 and T3 were verified by Guccione et al., 2014 for Chlorella sp. grown in BG11 medium (fresh water - based medium), with a content of $26.1 \mathrm{~g} / 100 \mathrm{~g}$, and lower value was verified with a yield of $14.6 \mathrm{~g} / 100 \mathrm{~g}$ in the biomass of cultivated Chlorella vulgaris. in the medium 3NBBM + V (modified Bold Basal medium) (Slocombe et al., 2015).

It was found a total of 18 amino acids in the T3 treatment and 17 amino acids in the CT, T1, $\mathrm{T} 2$, T4 and T5 treatments. In the T3 treatment a tryptophan content of $0.16 \mathrm{~g} / 100 \mathrm{~g}$ was quantified. In other treatments, the tryptophan content was not observed. Similarly, amino acid production in the biomass of Chlorella pyrenoidosa species grown in $\mathrm{F} / 2$ medium (Guillard) produced 18 amino acid types, including tryptophan, with a higher dry biomass concentration of $2.5 \mathrm{~g} / 100 \mathrm{~g}$ (Slocombe et al., 2015). In all treatments, the highest concentration was observed for the essential amino acids, followed by the conditionally essential and in lower concentration the non-essential amino acids. Among the essential amino acids, the highest concentration was L-leucine, the conditionally essential was L-arginine and non-essential L-glutamic acid. 
Table 4. Amino Acid profile (g/ $100 \mathrm{~g}$ ) of Chlorella sp. submitted to different treatments

\begin{tabular}{|c|c|c|c|c|c|c|}
\hline \multirow{2}{*}{ Amino acids } & \multicolumn{6}{|c|}{ Treatments (g / $100 \mathrm{~g})$} \\
\hline & CT & $\mathrm{T} 1$ & $\mathrm{~T} 2$ & T3 & $\mathrm{T} 4$ & T5 \\
\hline L-Phenylalanine * & 1.82 & 1.69 & 1.53 & 1.24 & 1.07 & 1.06 \\
\hline $\mathrm{L}-$ Lysine $*$ & 2.02 & 1.87 & 1.75 & 1.49 & 1.11 & 1.10 \\
\hline Tryptophan * & - & - & - & 0.16 & - & - \\
\hline L-Threonine $*$ & 2.43 & 2.22 & 2.17 & 1.58 & 1.33 & 1.30 \\
\hline $\mathrm{L}$ - Isoleucine * & 2.70 & 2.43 & 2.15 & 1.38 & 1.38 & 1.31 \\
\hline $\mathrm{L}-$ Leucine $*$ & 3.00 & 2.76 & 2.49 & 1.83 & 1.64 & 1.61 \\
\hline $\mathrm{L}-$ Arginine $* *$ & 3.72 & 3.35 & 3.03 & 2.42 & 1.94 & 1.89 \\
\hline $\mathrm{L}-$ Proline $* *$ & 1.55 & 1.65 & 1.61 & 1.62 & 1.02 & 1.03 \\
\hline $\mathrm{L}-$ Tyrosine $* *$ & 1.81 & 1.60 & 1.39 & 0.97 & 0.91 & 0.87 \\
\hline $\mathrm{L}-$ Cystine $* *$ & 0.33 & 0.31 & 0.16 & 0.13 & 0.22 & 0.20 \\
\hline $\mathrm{L}-$ Serine $* *$ & 2.00 & 1.77 & 1.60 & 1.36 & 0.99 & 0.97 \\
\hline Glycine ** & 2.06 & 1.91 & 1.77 & 1.26 & 1.19 & 1.17 \\
\hline $\mathrm{L}-$ Histidine $* *$ & 0.74 & 0.66 & 0.56 & 0.60 & 0.36 & 0.33 \\
\hline L-Alanine & 2.80 & 2.58 & 2.34 & 1.44 & 1.60 & 1.56 \\
\hline L-Aspartic Acid & 1.51 & 1.06 & 0.69 & 1.33 & 0.33 & 0.26 \\
\hline L-Glutamic Acid & 4.79 & 3.97 & 3.21 & 2.37 & 1.44 & 1.33 \\
\hline Total & 36.56 & 32.83 & 29 & 23 & 18.45 & 17.79 \\
\hline
\end{tabular}

* Essential amino acids; ** Conditionally essential amino acids; too many are nonessential

\subsection{Mechanical Hydrolysis and SEM of Biomass}

Ultrafine grinding allows the production of ultrafine powders, with a significant increase in the specific surface area, as well as other desirable properties, such as amorphization and greater chemical reactivity due to the increase in free energy on the particle surfaces (Tavares et al., 2001). The increase in the grinding time can lead to fracture, change in the shape and agglomeration of particles. These consequences also lead to a change in the porosity of the components produced from this material (Tavares, 2005).

Analyzing the results of the high-energy wet milling of Chlorella spp. (Figure 3), the CT, T1, T2 and T3 treatments have surfaces with a greater amount of amorphous materials, "possibly plasticized starches" in relation to the T4 and T5 treatments, and in all treatments it is possible to check points of crystalline materials overlapping. 


\section{Macrothink}
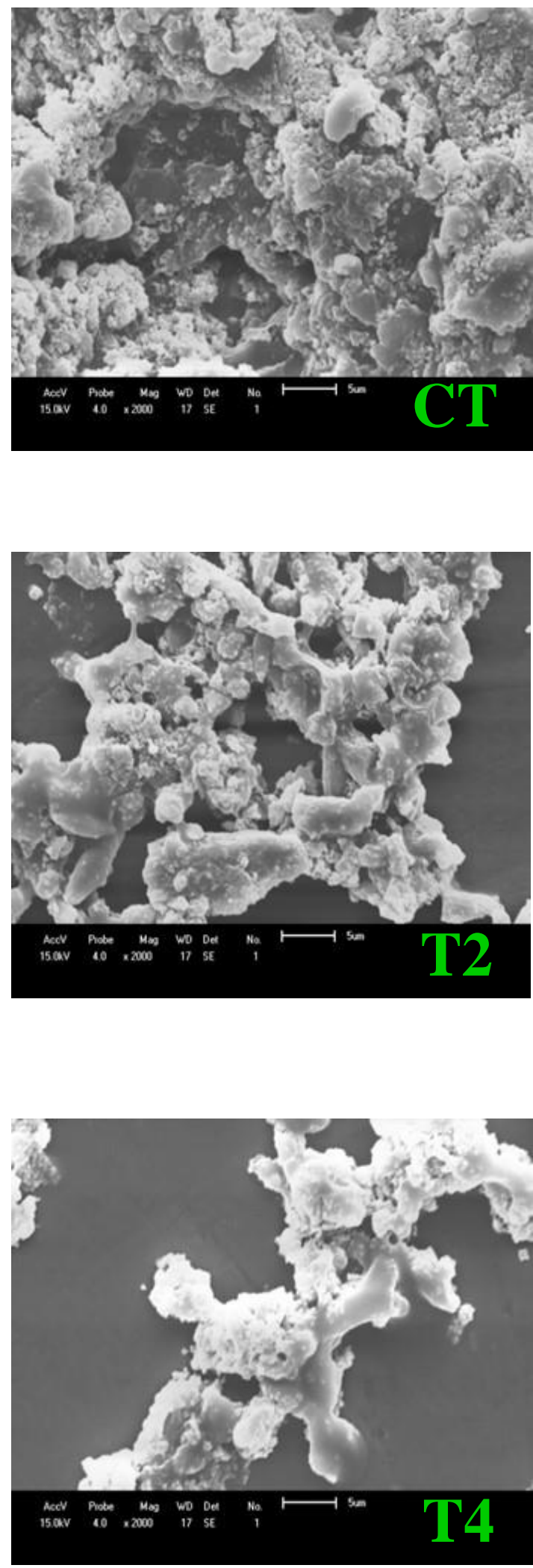

Journal of Agricultural Studies ISSN 2166-0379 2020, Vol. 8, No. 2
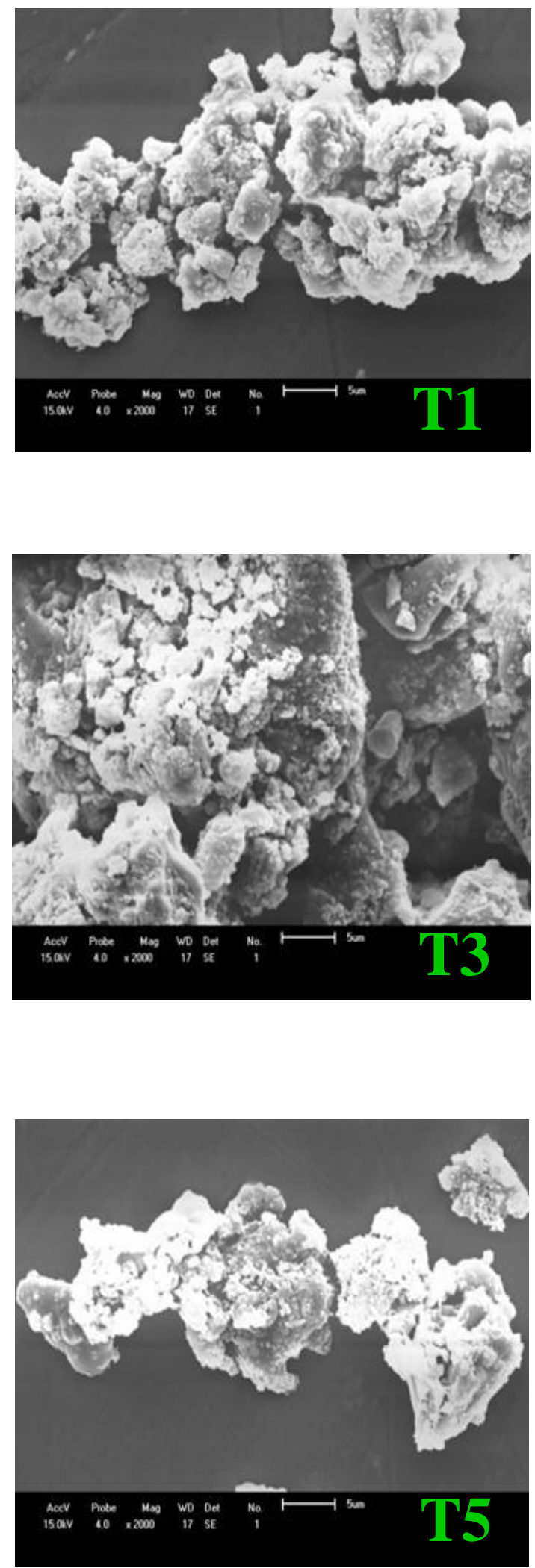

Figure 3. Micrograph of the mechanical hydrolysis of Chlorella sp biomass submitted to different treatments

It was found that the best grinding time was obtained at $15 \mathrm{~min}$, speed $400 \mathrm{rpm}$, with 
percentile sizes of $80 \mathrm{~nm}$, (Table 5). The hydrolysis parameters presented different configurations, in relation to the grinding time, with the following averages: interval of 5 minutes $551 \mathrm{~nm}, 10$ minutes $183 \mathrm{~nm}, 15$ minutes $80 \mathrm{~nm}$ and 20 minutes $199 \mathrm{~nm}$ (Table 5). The results obtained show that the high energy grinding must be adjusted to the characteristics of each material. In this study, the times 5 and 10 minutes were insufficient to reach the ideal granulometry ( $\sim 80$ to $100 \mathrm{~nm}$ ), while time of 20 minutes caused the increase in particle size. This phenomenon possibly occurred due to the release of polysaccharides contained in the cell walls causing plasticizing effects, molecular clusters and changes in hydrolysis results, as mentioned in Bello, et al., 2015.

Table 5. Analysis of micrographs of mechanical hydrolysis of Chlorella sp. CT, T1, T2, T3, T4 and T5, through Image-Pro Plus 7.0 software

\begin{tabular}{c|cccccc}
\hline \multicolumn{7}{c}{ Average Particle Size (nm) } \\
\hline Grinding time & CT & T1 & T2 & T3 & T4 & T5 \\
5 min & 571 & 549 & 554 & 528 & 562 & 541 \\
$10 \mathrm{~min}$ & 182 & 176 & 193 & 171 & 185 & 190 \\
$15 \mathrm{~min}$ & 87 & 74 & 83 & 94 & 65 & 77 \\
$20 \mathrm{~min}$ & 207 & 201 & 198 & 185 & 211 & 194 \\
\hline
\end{tabular}

In a case study, the reduction in the size of particles of bioative materials led to the high-energy grinding of a drug named "Efavirenz", increasing its solubility, indicating a strategy to increase both the solubility and its effects. In another study with coconut fiber, it was evaluated the properties and the production of particles of coconut fiber, and it was found that after increasing the grinding time, structural changes occurred, as well as synthesis of new compounds during the procedure (Bello, et al., 2015). The standardization of wet milling might be strategic for the sector of production of plant biostimulants, mainly beacuse the costs with enzymatic hydrolysis and other methods may not be viable when applied at scale. Thus, our proposal here was to start a preliminary investigation, and future work is needed to deepen these investigations.

\subsection{Seedling Biostimulation}

Biostimulants are products that, when applied in low concentrations, help the twinning, development, and productivity of plants, regulating and improving their physiological processes (Kawalekar, 2013; Toscano, et al., 2018). It is pivotal to study the feasibility to produce biomass as bioestimulants, to analyze their composition and active ingredients. Currently, some studies have investigated the application of algae biomass as a raw material for use in agriculture (Elarroussi et al., 2016). Here, we analyzed the bio-stimulating potential of Chlorella sp. produced in different concentrations of nutrients (CT and $\mathrm{T}$ treatments). The results obtained 
demonstrated that the extracts of Chlorella sp. produced by mechanical hydrolysis were able to biostimulate germination and the development of yellow melon seedlings (Tables 6 and 7).

As shown in Table 6, the best results were obtained of biomass from treatments T2, T4 and T5, for the germination index (IG) 92.00, 92.00 and 95.00\%, germination speed index (GSI) 8.00000, 8.00000 and 8.26087 seedlings / day and the average germination time (AGT) 7.66667, 7.66667 and 7.91667 days, respectively. Analyzing the intercalations between the effects obtained in the germination and the modulation of the means of cultivation of the microalgae Chlorella sp. it was noticed that, even reducing the levels of macro elements in the treatments, the biostimulant effect was greater in the treatments modulated with lower concentrations of NPK, even though there was a reduction in protein synthesis in these treatments (Table 4). It is suspected that the production of peptides with the biostimulant function may have occurred in specific medium composition, a fact that we will investigate in future research.

The results obtained for Seedling Height (SH), Fresh Mass from the Aerial Part (FMAP) and Dry Mass from the Aerial Part (DMAP) were significant for the T2 treatment with values of 50.99 $\mathrm{mm}, 0.94$ and $0.12 \mathrm{~g}$, respectively, compared to other treatments. The number of leaves (NL) showed no significant difference between all treatments. Best Root Length (RL) was obtained in treatment T1, with a value of $91.80 \mathrm{~mm}$. For Dry Root Mass (DRM), the best stimulation occurred in treatment T5 with a value of $0.6 \mathrm{~g}$. For seedlings color there was no statistical difference between all treatments, as shown in Table 7 .

Table 6. Values of analysis of variance of parameters of biostimulation of seedlings of (Cucumis melo L.) by the biomass of Chlorella sp. in different procedures

Treatment averages

\begin{tabular}{cccc}
\hline Treatments & GP & GSI & AGT \\
\cline { 2 - 4 } CT & $51.00^{\mathrm{ns}}$ & $4.47826^{\mathrm{ns}}$ & $4.29167^{\mathrm{ns}}$ \\
$\mathrm{n} 1$ & $59.00^{\mathrm{ns}}$ & $5.13043^{\mathrm{ns}}$ & $4.91667^{\mathrm{ns}}$ \\
$\mathrm{T} 2$ & $92.00^{* *}$ & $8.00000^{* *}$ & $7.66667^{* *}$ \\
$\mathrm{~T} 3$ & $63.00^{*}$ & $5.52174 *$ & $5.29167^{*}$ \\
$\mathrm{~T} 4$ & $92.00^{* *}$ & $8.00000^{* *}$ & $7,66667^{* *}$ \\
$\mathrm{~T} 5$ & $95.00^{* *}$ & $8.26087^{* *}$ & $7.91667^{* *}$ \\
\hline $\mathrm{CV}(\%)$ & 1.63 & 0.26000 & 1.63170
\end{tabular}

GP germination percentage; GSI = germination speed index; AGT = Average germination time; ** significant at $1 \%$; significant at 5\%; ns not significant. 


\section{Ml Macrothink}

Overall, our results suggest that the modulation of Chlorella sp. growth medium played a fundamental role in the biostimulation of seedlings of yellow melon, mainly in the increase of the mass gain and in the lengthening of the stem. Some recent studies have been demonstrated the biostimulant effects of microalgae biomass. For instance, Ronga et al. (2019) studied a set of microalgae, including Chlorella vulgaris, which showed a high rate of stimulus to seed germination, with an increase in the germination rate around $144.51 \%$. Barone et al. (2018a) tested extracts of microalgae of $C$. vulgares, $S$. quadrilata and $C$. vulgares on sugar beet, obtaining stimulation of root growth and increased plant growth and development. Moreover, Navarro-López et al. (2020) tested the effects of Scenedesmus obliquo extracts in mung bean and cucumber cultures, obtaining promising results, demonstrating stimulating effects both from phyto-endogenous hormones and amino acids contained in the extracts, corroborating with the results obtained in the present study.

Table 7. Summary of analysis of variance for the variables: seedling height (SH), number of leaves (NL), root length (RL), fresh mass from the aerial part (FMAP), fresh root mass (FRM), dry mass from the aerial part (DMAP), root dry mass (RDM), $\mathrm{L}^{*}, \mathrm{a}^{*}$ and $\mathrm{b}^{*}$ : color of yellow melon seedlings stimulated with microalgae biomass

\begin{tabular}{lccccc}
\hline \multirow{2}{*}{ TREATMENT } & \multicolumn{5}{c}{ Averages of Treatments } \\
\cline { 2 - 6 } & SH & NL & RL & FMAP & FRM \\
\hline CT & $38.90 \mathrm{~b}$ & $1.06 \mathrm{a}$ & $91.80 \mathrm{a}$ & $0.78 \mathrm{~b}$ & $0.53 \mathrm{ab}$ \\
T1 & $39.16 \mathrm{~b}$ & $1.00 \mathrm{a}$ & $60.79 \mathrm{~b}$ & $0.70 \mathrm{~b}$ & $0.73 \mathrm{a}$ \\
T2 & $50.99 \mathrm{a}$ & $1.00 \mathrm{a}$ & $58.37 \mathrm{~b}$ & $0.94 \mathrm{a}$ & $0.67 \mathrm{ab}$ \\
T3 & $37.92 \mathrm{~b}$ & $1.06 \mathrm{a}$ & $59.90 \mathrm{~b}$ & $0.77 \mathrm{~b}$ & $0.59 \mathrm{ab}$ \\
T4 & $43.34 \mathrm{~b}$ & $1.00 \mathrm{a}$ & $52.67 \mathrm{~b}$ & $0.81 \mathrm{~b}$ & $0.69 \mathrm{ab}$ \\
T5 & $41.28 \mathrm{~b}$ & $1.00 \mathrm{a}$ & $68.93 \mathrm{~b}$ & $0.78 \mathrm{~b}$ & $0.51 \mathrm{~b}$ \\
\hline & DMAP & DRM & L* & $\mathrm{a}^{*}$ & $\mathrm{~b} *$ \\
\hline CT & $0.11 \mathrm{ab}$ & $0.03 \mathrm{~b}$ & $30.06 \mathrm{a}$ & $17.53 \mathrm{a}$ & $36.06 \mathrm{a}$ \\
T1 & $0.09 \mathrm{c}$ & $0.04 \mathrm{ab}$ & $36.53 \mathrm{a}$ & $17.73 \mathrm{a}$ & $36.53 \mathrm{a}$ \\
T2 & $0.12 \mathrm{a}$ & $0.05 \mathrm{ab}$ & $36.91 \mathrm{a}$ & $17.94 \mathrm{a}$ & $36.91 \mathrm{a}$ \\
T3 & $0.10 \mathrm{bc}$ & $0.04 \mathrm{ab}$ & $35.20 \mathrm{a}$ & $17.52 \mathrm{a}$ & $35.20 \mathrm{a}$ \\
T4 & $0.09 \mathrm{bc}$ & $0.05 \mathrm{ab}$ & $36.71 \mathrm{a}$ & $17.53 \mathrm{a}$ & $36.71 \mathrm{a}$ \\
T5 & $0.08 \mathrm{c}$ & $0.06 \mathrm{a}$ & $36.34 \mathrm{a}$ & $17.54 \mathrm{a}$ & $36.34 \mathrm{a}$ \\
\hline
\end{tabular}

Means followed by the same letter in the columns do not differ statistically by Tukey test at $5 \%$ probability level.

\section{Conclusions}

Modulation of the cultivation of Chlorella sp. in different concentrations of nutrients alters biomass yield, amino acids profile and bioestimulant properties. It was shown that intermediary levels of NPK (nitrogen, phosphate, potassium), and carbon source (T2 treatment) allowed strong bioestimulant effects on melon (Cucumis melo L.) germination, influencing stem elongation and 
amount of fresh and dry matter of the aerial part of seedlings. In addition, low levels of NPK and increased levels of $\mathrm{C}$ had strong effects on bioestimulant germination properties of Chlorella biomass, as characterized by increased germination percentage (GP), germination speed index (GSI) and average germination time (AGT). These results indicate that the balance of nutrients in the cultivation medium is pivotal for the bioestimulant effects of Chlorella sp. biomass, despite the biomass yield. Future research is needed to characterize the peptide and other components in the biomass of Chlorella sp after the growth modulation, to elucidate the bioestimulant mechanisms of its biomass.

\section{References}

Aguirre-cruz, A. A. et al. (2010). Moisture adsorption behavior of banana flours (Musa paradisíaca) unmodified and modified by acid-treatment, Starch, 62, 658-666. https://doi.org/10.1002/star.201000028

Alcântara, S. R. et al. (2009). Isoterma de adsorção do pendúnculo seco do caju. Revista Brasileira de Engenharia Agricola e Ambiental, 13, 81-87. https://doi.org/10.1590/S1415-43662009000100012

Alexandre, H. V., Figueirêdo, R. M. F., \& Queiroz, A. J. M. (2007). Isotermas de adsorção de umidade da pitanga em pó. Revista de Biologia e Ciências da Terra, 7, 11-20.

Al-Muhtaseb, A. H. W. A. M., Mcminn, W. A. T. R. A., \& Magee, T. R. A. (2004). Water sorption isotherms of starch powders Part 1: mathematical description of experimental data. Journal of Food Engineering, 61, 297-307. https://doi.org/10.1016/S0260-8774(03)00133-X

Anastasakis, K., \& Ross, A. B. (2011). Hydrothermal liquefaction of the brown macroalga Laminaria saccharina: effect of reaction conditions on product distributionand composition. Bioresour. Technol, 102, 4876-4883.

Barone, V. et al. (2018a). Root morphological and molecular responses induced by microalgae extracts in sugar beet (Beta vulgaris L.). J. Appl. Phycol, 30, 1061-1072. https://doi.org/10.1007/s10811-017-1283-3

Baumgartner, T. R. S. (2013). Avaliação da produtividade da microalga Scenedesmus acuminatus (Lagerheim) Chodat em diferentes meios de cultivo. Revista Brasileira de Biociencias, 11, 250-255. http//www.ufrgs.br/seerbio/ojs/index.php/rbb/article/view/2541

Becker, E. W. (1994). Microalgae Biotechnology and microbiology. Cambridge, Cambridge University Press, 301.

Bello, S. A., Agunsoye, J. O., \& Hassan, S. B. (2015). Synthesis of coconut shell nanoparticles through a top-down approach: the grinding duration of the evaluation in the sizes and morphologies of particles coconut shell nanoparticles Materials Letters, 159, 514-519. https://doi.org/10.1016/j.matlet.2015.07.063

Bertoldi, F. C., Sant'Anna, E., \& Oliveira, J. L. B. (2008a). Revisão: Biotecnologia de Microalgas. Boletim Centro de pesquisa de processamento de alimentos, 26, 9-20. https://doi.org/10.5380/cep.v26i1.11804

Bhusari, S. N., Muzaffar, K., \& Kumar, P. (2014). Moisture sorption isotherms and storage 
study of spray dried tamarindo pulp poder. Powder Technology, 291, 322-327. https://doi.org/10.1016/j.powtec.2014.06.038

Blahovec, J. (2004). Sorption isotherms in materials of biological origin mathematical and physical approach. Journal of Food Engineering, 65, 489-495. https://doi.org/10.1016/j.jfoodeng.2004.02.012

Brunauer, S. et al. (1940). On a theory of Van der Waals adsorption of gases. Journal of the American Chemical Society, 62, 1723-1732. https://doi.org/10.1021/ja01864a025

Cano-Higuita, D. M. et al. (2015). Influence of alternative drying aids on water sorption of spray dried mango mix powders: A thermodynamic approach. Food and Bioproducts Processing, 93, 19-28. https://doi.org/10.1016/j.fbp.2013.10.005

Cappelleto, E. et al. (2017). Microstructural effects of high-energy grinding in poorly soluble drugs the case study of efavirenz. Powder Diffraction, 32, 135-140. https://doi.org/10.1016/j.msec.2017.04.055

Cappelletto, E. et al. (2018). Mechanical activation of Efavirenz: effects on dissolution and inhibitor behavior, Pharmaceutical Development and Technology, 23, 1128-1135. https://doi.org/10.1080/10837450.2018.1469148

Chisté, R. C. et al. (2012). Sorption isotherms of tapioca flour. International Journal of food Science and Technology, 47, 870-874. https://doi.org/10.1111/j.1365-2621.2011.02900.x

Chojnacka, K. et al. (2014). Innovative Natural Plant Growth Biostimulants. In Advances in Fertilizer Technology II Biofertilizers. Studium Press LLC, 1, 21.

Cladera-oliveira, et al. (2011). Modeling water adsorption isotherms of Pinhão (Araucária angustifólia seeds) flour and thermodynamic analysis of the adsoption process. Journal of Process Engineering, 34, 826-843. https://doi.org/10.1111/j.1745-4530.2009.00437.x

Colla, G. et al. (2014). Biostimulant action of a plant-derived protein hydrolysate produced through enzymatic hydrolysis. Frontiers in plant Science, 5, 448. https://doi.org/10.3389/fpls.2014.00448

Colla, G. et al. (2016). Protein hydrolysate-based biostimulants: origin, biological activity and application methods. Acta Horticulturae, 1148, 27-34. https://doi.org/10.17660/ActaHortic.2016.1148

Colla, G., \& Rouphael, Y. (2015). Biostimulants in horticulture. Scientia. Horticulturae. 196, 1-2. https://doi.org/10.1016/j.scienta.2015.10.044

Crapiste, G. H., \& Rotstein, E. (1982). Prediction of sorption equilibrium data for starch-containing foodstuffs. Journal of Food Science, 47, 1501-1507.

Cui, Y. et al. (2018). Moisture-Resistant Co-Spray-Dried Netilmicin with L-Leucine as Dry Powder Inhalation for the Treatment of Respiratory Infections. Pharmaceutics, 10, 252. https://doi.org/10.3390/pharmaceutics10040252

Dias, G. A. et al. (2019). Biomass of Microalgae via Root Under the Production of Yellow Passionfruit Seedlings. Journal of Agricultural Science, 11, 105-112. https://doi.org/10.5539/jas.v11n6p105 
Elarroussi, H. et al. (2016). Microalgae polysaccharides a promising plant growth biostimulant. Journal. Algal Biomass Utilization, 7, 55-63.

Fabra, M. J. et al. (2011). Effect of maltodextrins in the water-content-water activity-glass transition relationships of noni (Morinda citrifolia L.) pulp poder. Journal of Food Engineering, 103, 47-51. https://doi.org/10.1016/j.jfoodeng.2010.09.018

Ferreira, D. F. (2011). SISVAR: A computer statistcal analysis system. Science and Agrotechnology, 35, 1039-1042.

Gabas, A. L. et al. (2009). Propiedades termodinámicas de sorción de agua de la pulpa de lulo en polvo com encapsulantes. Ciências e Tecnologia de Alimentos, 29, 911-918. https://doi.org/10.1590/S0101-20612009000400032

Goula, A. M. et al. (2008). Adamopoulos. Water sorption isotherms and glass transition temperature of spray dried tomato pulp. Journal of Food Engineering, 85, 73-83. https://doi.org/10.1016/j.jfoodeng.2007.07.015

Guccione, A. et al. (2014). Chlorella for protein and biofuels: from strain selection to outdoor cultivation in a Green Wall Panel photobioreactor. Biotechnology for Biofuels, 5, 1-12. https://doi.org/10.1186/1754-6834-7-84

Guedes, W. A. et al. (2018). Production of Papaya Seedlings Using Spirulina platensis as a Biostimulant Applied on Leaf and Root. Journal of Experimental Agriculture International, 28, 1-9. https://doi.org/10.9734/JEAI/2018/45053

Hagen, S. R., Frost, B., \& Augustin, J. (1989). Pre-column phenylisothiocynate derivatization and liquid-chromatography of aminoacids in food. Journal of the Association of Official Analytical Chemists, 72, 912-916. https://doi.org/10.1016/j.biortech.2011.01.031

Jelínek, L. et al. (2015). Chlorella vulgaris biomass enriched by biosorption of polyphenols. Algal Research, 10, 1-7. https://doi.org/10.1016/j.algal.2015.04.006

Kawalekar, J. S. (2013). Papel dos biofertilizantes e biopesticidas na agricultura sustentável. Journal Bio Innovation, 3, 73-78.

Khan, W. et al. (2009). Seaweed Extracts as Biostimulants of Plant Growth and Development. Journal Plant Growth Regulation, 28, 386-399. https://doi.org/10.1007/s00344-009-9103-x

Konig-Péter, A. et al. (2015). Biosorption characteristics of Spirulina and Chlorella cell for the accumulation of heavy metals. Journal Serbian Chemical Society, 80, 407-419. https://doi.org/10.2298/JSC140321060P

Labourlau, L. G. (1983). Seed germination. General Secretary of OEA, Washington, 174p.

Li, Y. et al. (2011). Characterization of a microalga Chlorella sp. well adapted to highly concentradet municipal wastewater for nutrient removal and biodiesel production. Bioresource Technology, 102, 5138-5144. https://doi.org/10.1016/j.biortech.2011.01.091

Lima, E. E. et al. (2008). Estudo das isotermas e calor isostérico de adsorção da farinha da coroa de frade. Revista Brasileira de Produtos Agroindustriais, 10, 163-170. https://doi.org/10.15871/1517-8595/rbpa.v10n2p163-170

Lira, R. A. DSc... Universidade Federal de Viçosa Agosto de (2011). Estudo do rendimento 
de biomassa da microalga nativa Chlorella sp. visando a obtenção de biocombustíveis. Tese de Doutorado.

Lourenço, S. O. (2006). Cultivo de microalgas marinhas - princípios e aplicações. São Carlos: RiMa, 588p. Biblioteca(s) Embrapa Agroenergia

Lu, N. et al. (2016). Global metabolic regulation of the snow alga Chlamydomonas nivalis in response to nitrate or phosphate deprivation by a metabolome profile Analysis. International Journal Molecules Sciences, 17, 1-19. https://doi.org/10.3390/ijms17050694

Maguire J D. (1962). Speed of germination - aid in selection and evaluation for seedling emergence and vigor. Crop Science. $2, \quad$ 176-177. https://doi.org/10.2135/cropsci1962.0011183X000200020033x

Martin, A., \& Francisco, G. (2014). A Single-Step Method for Rapid Extraction of Total Lipids from Green Microalgae. Plos one, 9, 43-64. https://doi.org/10.1371/journal.pone.0089643

Matos, Â. P. (2012). Potentialities of Chlorella vulgaris grown in a desalination concentrate (dissertation) / Ângelo Paggi Matos; advisor, Ernani Sebastião Sant 'Anna. Florianopolis, SC.

Mcminn, W. A. M., \& Magee, T. A. (2003). Thermodynamic properties of moisture sorption of potato. Journal of Food Engineering, 60, 157-165. https://doi.org/10.1016/S0260-8774(03)00036-0

Melo, R. O. et al. (2008). Susceptibilidade à compactação e correlação entre as propriedades físicas de um Neossolo sob vegetação de caatinga. Revista Caatinga, 21, 12-17.

Michalak, I., \& Chojnacka, K. (2016). The potential usefulness of a new generation of agro-products based on raw materials of biological origin. Acta Scientiarum. Polonorum. Hortorum Cultus, $\quad 15, \quad 97-120$. http://www.hortorumcultus.actapol.net/volume15/issue6/15_6_97.pdf

Michalak, I., \& Chojnacka, K. (2017). Saeid, A. Plant Growth Biostimulants, Dietary Feed Supplements and Cosmetics Formulated with Supercritical CO2 Algal Extracts. Molecules, 22, 66. https://doi.org/10.3390/molecules22010066

Mokashi, K. et al. (2016). Sodium bicarbonate as inorganic carbon source for higher biomass and lipid production integrated carbon capture in Chlorella vulgaris. Achievements in the Life Sciences, 10, 111-117. https://doi.org/10.1016/j.als.2016.05.011

Morais, M. G., \& Costa, J. A. V. (2007). Biofixation of carbon dioxide by Spirulina sp. and Scenedesmus obliquus cultivated in a three-stage serial tubular photobioreactor. Journal. Biotechnology, 129, 439-445. https://doi.org/10.1016/j.jbiotec.2007.01.009

Navarro-López, E. et al. (2020). Biostimulant potential of Scenedesmus obliquus grown in brewery wastewater. Molecules, 25, 1-16. https://doi.org/10.3390/molecules25030664

Niels, H., Ingolf, P., \& Frank, B. (2012). Biomass productivity and productivity of fatty acids and amino acids of microalgae strains as key characteristics of suitability for biodiesel production. Journal applied Phycology, 24, 1407-1418. https://doi.org/10.1007/s10811-012-9795-3 
Oliveira, E. G. et al. (2009a). Characterization of thin layer drying of Spirulina platensis utilizing perpendicular air flow. Bioresource Technology, 100, 1297-1303. https://doi.org/10.1016/j.biortech.2008.05.052

Oliveira, E. G. et al. (2009b). Moisture sorption characteristics of microalgae Spirulina platensis. Brazilian Journal of Chemical Engineering, 26, 189-197. https://doi.org/10.1590/S0104-66322009000100018

Park, K. J. B. et al. (2014). Secagem: fundamentos e equações. Revista Brasileira de Produtos Agroindustriais, 16, 93-127.

Patrick, D. J. et al. (2015). Plant biostimulants: Definition, concept, main categories and regulation. Scientia Horticulturae, 196, 3-14. https://doi.org/10.1016/j.scienta.2015.09.021

Putri, E. V. et al. (2011). Investigation of Microalgae for High Lipid Content using Palm Oil Mill Effluent (Pome) as Carbon Source 2011 International Conference on Environment and Industrial Innovation. International Proceedings of Chemical, Biological and Environmental Engineering, 12, 25-45.

Rezaei, H., Kulkarni, S. D., \& Saptarshi, P. G. (2011). Study of Physical Chemistry on Biosorption of Nickel by using Chlorella pyrenoidosa. African Journal of Pure and Applied Chemistry, 14, 474-485. http://www.academicjournals.org/AJPAC

Ribeiro L. C., Costa, J. M. C., \& Afonso, M. R. A. (2016). Hygroscopic behavior of lyophilized acerola pulp powder. Revista Brasileira de Engenharia Agrícola e Ambiental, 20, 269-274. https://doi.org/10.1590/1807-1929/agriambi.v20n3p269-274

Ricci, M. et al. (2019). General principles to justify claims of plant biostimulants. Frontiers in Plant Science, 10, 1-10. https://doi.org/10.3389/fpls.2019.00494

Ronga, D. et al. (2019). Microalgal Biostimulants and Biofertilisers in Crop Productions. Agronomy, 9, 1-22. https://doi.org/10.3390/agronomy9040192

Rouphael, Y., \& Colla, G. (2018). Synergistic biostimulatory action: Designing the next generation of plant biostimulants for sustainable agriculture. Frontiers. Plant Science, 9, 1655. https://doi.org/10.3389/fpls.2018.01655

Sanchez, T. et al. (2008). Estudio cinético e isotermas de adsorcion de Ni (II) y Zn (II) utilizando del alga Chlorella sp. Inmovilizada. Ciencia Universidad Autónoma de Nuevo león, 5, 168-176. http://eprints.uanl.mz/ideprint/1876

Silva, R. N. G. et al. (2015). Isotermas de adsorção de umidade do umbu-cajá em pó. Educação Agrícola Superior, 30, 33-36. https://doi.org/10.12722/0101-756X.v30n01a07

Slocombe, S. P. et al. (2015). Unlocking nature`s treasure-chest: screening for oleaginous algae. Scientific Reports, 5, 694-703. https://doi.org/10.1038/srep09844

Spada, J. C. et al. (2013). Water adsorption isotherms of microcapsules with hydrolyzed Pinhão (Araucária angustifólia seeds) Starch a wall moisture. Journal of food Engineering, 114, 64-69. https://doi.org/10.1016/j.jfoodeng.2012.07.019

Spies, J. R. (1967). Determination of tryptophan in proteins. Analytical Chemistry, 39, 1412-1416. https://doi.org/10.1021/ac60256a004 


\section{Macrothink

Stirk, W. A. et al. (2013). Auxin and cytokinin relationships in 24 microalgal strains 1. Journal of Phycology, 49, 459-467. https://doi.org/10.1111/jpy.12061

Stirk, W. A. et al. (2013). Hormone profiles in microalgae: Gibberellins and brassinosteroids. Plant Physiology. Biochemisthy, 70, 348-353. https://doi.org/10.1016/j.plaphy.2013.05.037

Tavares, L. M. M. (2005). Unit operations in mineral processing - An introduction to the theoretical and practical aspects of the preparation of mineral raw materials. COPPE/UFRJ, Rio de Janeiro, 20-21.

Tavares, L. M. M., Cabral, A. J. O., \& Ogasawara, T. (2001). Preparation of sub-micrometric iron oxide for application in magnetic ceramics by high energy grinding. Matéria, 6, 1-7.

Toscano, S et al. (2018). Biostimulant applications in low input horticultural cultivation systems. Italus Hortus, 25, 27-36. https://doi.org/10.26353/j.itahort/2018.1.2736

Trevisan, E., Zandonadi, B. K., \& Arroyo, F. B. P. A. (2019). Thermogravimetric evaluation of cultivated Chlorella vulgaris biomass in different nutritional conditions. Engevista, 21, 242-255. https://doi.org/10.22409/engevista.v21i2.22842

Watanabe. A. (1960). List of algal strains in collection at the Institute of applied microbiology University of Tokyo. Journal of General and Applied Microbiology, 6, 1-4.

White, J. A., Hart, R. J., \& Fry, J. C. (1986). An evaluation of the waters Pico-Tag System for the aminoacids analysis of food materials. Journal of Automatic Chemistry, 8, 170-177. https://doi.org/10.1155/S1463924686000330

Yakhin, O. I. et al. (2016). Biostimulants in plant sciences: a global perspective. Frontiers in Plant Science, 7, 1-32. https://doi.org/10.3389/fpls.2016.02049

Zielinski, D. et al. (2020). Biological Activity of Hydrophilic Extract of Chlorella vulgaris Grown on Post-Fermentation Leachate from a Biogas Plant Supplied with Stillage and Maize Silage. Molecules, 25, 1-18. https://doi.org/10.3390/molecules25081790

\section{Copyright Disclaimer}

Copyright for this article is retained by the author(s), with first publication rights granted to the journal.

This is an open-access article distributed under the terms and conditions of the Creative Commons Attribution license (http://creativecommons.org/licenses/by/4.0/). 